\title{
CLIMATE CHANGE, BIOLOGICAL INVASION AND EMERGING DISEASES: A LONGITUDINAL SOCIOLOGICAL STUDY MONITORING THE SPREAD OF ASIAN TIGER MOSQUITOES IN A EUROPEAN REGION
}

\author{
Cécilia Claeys and Elise Mieulet
}

\author{
Aix-Marseille University IRD LPED \\ Jardin du Pharo, 58 Boulevard Charles Livon, 13284 Marseille, France \\ e-mail: cecilia.claeys@univ-amu.fr
}

\begin{abstract}
The consequences of climate change on public health can be direct or indirect such as, for example, by modifying vector species distribution. This is the case with Aedes albopictus, a mosquito that is a vector for dengue fever, chikungunya, and potentially the Zika virus. This article focuses on the Alpes-Maritimes department, the first French department affected by the introduction of $A$. albopictus, i.e. the "Asian tiger mosquito". It draws on qualitative and quantitative diachronic research conducted from 2009 to 2014 to provide a time-dependent sociological analysis of the implementation of chikungunya and dengue prevention policies and their reception by the population of the Alpes-Maritimes. The article first compares scientific expertise and the discourse of inhabitants regarding the climatic and anthropogenic factors that have encouraged the introduction and proliferation of tiger mosquitoes. It then highlights how both policy-makers and inhabitants must mediate between the epidemic-related and environmental challenges that have accompanied the spread of A. albopictus. Finally, the paper examines the (un)acceptance of the population vis-à-vis this invasive exotic species and points to the unequal capacity of different inhabitants to react when confronted with an environmental and health-related risk.
\end{abstract}

Keywords: Alpes-Maritimes, arboviruses, climate change, diachronic sociological analyses, tiger mosquito, relationship between environment / health.

\section{INTRODUCTION ${ }^{1}$}

The consequences of climate change on public health can be direct (e.g., heat waves) or indirect, for example, by modifying species distribution (Kent et al., 2014). This is the case of Aedes albopictus, a mosquito vector of dengue fever, chikungunya, and potenti-

1 Translated from French by Jocelyne A. L. Serveau. Ms Serveau is a professional English translator specialised in the social sciences and humanities. 
ally the Zika virus. A. albopictus, also known as the "Asian tiger mosquito", is indigenous to Southeast Asia. Since the late $20^{\text {th }}$ century, this invasive species has spread widely and can currently be found in Europe, North and South America, Africa and in the Pacific and Indian Oceans (Paupy et al., 2009). The intensification of global trade has facilitated the introduction of $A$. albopictus to new continents (Hawley, 1988; Medlock et al., 2012). Climate change, urbanisation and the ensuing loss of biodiversity ${ }^{2}$ have encouraged its proliferation (Gould et al., 2009; Ostfeld, 2009). Given this, the introduction and rapid expansion of the range of $A$. albopictus has exposed Europe to epidemic risks that, until recently, it had not faced before. The French Mediterranean coast has been particularly affected (Vazeille et al., 2008). Since the observation of its introduction in Menton, France in 2004, A. albopictus has rapidly expanded its range along the entire coast and has also begun to move northward (Medlock et al., 2012). In addition to new epidemic risks in the region (several autochthonous cases of dengue and chikungunya [Schnaffer, 2013]), there has also been a significant increase in discomfort, since the arrival of $A$. albopictus has exposed local inhabitants and tourists to a much greater degree of nuisance than previously (Claeys et Mieulet, 2013) as the tiger mosquito is indeed known for the intensity and frequency of its bites (Hawley, 1988; Medlock, 2012). Since 2009, we have been conducting sociological monitoring of the reactions of decision-makers and local inhabitants regarding the intrusion into mainland France of this exotic, nuisance biter species of vector mosquito. In the context of this article, we will focus on the Alpes-Maritimes department, the first French department affected by the introduction of $A$. albopictus. We will draw on qualitative and quantitative diachronic research conducted from 2009 to 2014 to provide a time-dependent sociological analysis of the implementation of chikungunya and dengue prevention policies and of their reception by the population in the Alpes-Maritimes. The aim of this paper is to provide some answers to the following three questions: To what degree is the spread of A. albopictus seen by scientists and inhabitants as a consequence of climate change? To what extent has the local population adapted to this exotic invasive vector mosquito and accepted public policy messages regarding both health and environmental issues? And finally, has the spread of $A$. albopictus fostered new forms of environmental and healthrelated vulnerability?

We will first present the theoretical and methodological framework employed, and divide our analysis into three sections, of which each will emphasise the diachronic evolution of the discourse and practices of social actors over the period studied. The first section compares scientific expertise and the discourse of inhabitants, and examines the climatic and anthropogenic factors that have encouraged the introduction and proliferation of tiger mosquitoes. The second section describes how both policy-makers

2 Loss of biodiversity within the mosquito fauna is also described as a consequence of the establishment of A. albopictus which is highly competitive, further encouraging potentially greater epidemic risk (Julianio and Lounibos, 2005). 
and inhabitants have had to mediate between the epidemic-related and environmental challenges that have accompanied the spread of $A$. albopictus, underscoring the ambiguity between the quest for comfort and health prevention. Finally, the third section discusses the (un)acceptance of the population vis-à-vis this invasive exotic species and points to the unequal capacity of different inhabitants to react to environmental and health-related vulnerability.

\section{THEORETICAL FRAMEWORK: CLIMATE CHANGE, THE ENVIRONMENT AND HEALTH}

Environmental issues are of growing concern in contemporary society (Dunlap and York, 2008). They have permeated into the political sphere (Mol et al., 2009), legal framework (Tarlock, 2009) and "public opinion" (European Commission, 2008), and more broadly constitute a new set of "ethics". Such "environmental ethics" and their internal logic (biocentrism / eco-centrism) ${ }^{3}$ (Light and Rolston, 2002) are at odds with the deeply rooted anthropocentric legacy of Western society. This tension exists not only in the broad spheres of society (notably production / protection), but can also be found within a single entity and even within individuals, thus revealing contradictory aspirations and inconsistencies between expressions of concern for the environment and the maintenance of anthropocentric practices and lifestyles (Dunlap and York, 2008). The issue of climate change is particularly conducive to this type of ambiguity. While the slogan "think globally, act locally" has been largely disseminated in contemporary society, decision-makers and citizens have nonetheless struggled to turn words into action. At the same time, the signs that climate change is indeed occurring are increasingly being confirmed, as are its effects on the environment and health, and this may in turn reinforce or affect pre-existing types of environmental and health-related vulnerability (Kent et al., 2014). The accumulation of or compensation for different types of vulnerability are in this respect one of the major issues addressed in research into the environment and health. A great deal of research has described situations of compounded disadvantages in which social, environmental and health-related vulnerabilities overlap and mutually reinforce each other (Sen, 1992; Gomes, 1993; Bullard, 2008; King and Crews, 2013). Among these are case studies about vector-borne infectious diseases (Sutherst, 2004). Proponents of this perspective argue that climate change tends to exacerbate situations of already marked environmental and health-related inequality (Kent et al., 2014). Other approaches, such as the seminal research of Ulrich Beck (1992), however have claimed that a reshaping of traditional social inequality is underway in the context of contemporary risk.

3 Biocentrism is based on a defence of the intrinsic value of each living entity, whereas eco-centrism underscores the interdependence of living beings belonging to a biotic community of which humans are also a part. 


\section{METHODOLOGY: DIACHRONIC OBSERVATION AND COMPLEMENTARITY BETWEEN QUALITATIVE AND QUANTITATIVE STUDIES}

This article is based on the corpora of data from two research programmes that were coordinated successively from 2009 to 2016 (see Table 1). ${ }^{4}$ They were conducted at different territorial scales, but each included some or all coastal municipalities in the Alpes-Maritimes department. The topography and demography of the Alpes-Maritimes have resulted in the co-presence of vector mosquitoes and human populations in its warm, densely urbanised coastal municipalities. That is why our qualitative and quantitative sociological studies conducted in 2009, 2010 and 2012 focused on the forty-eight municipalities of the Alpes-Maritimes department situated along the coastal fringe. The qualitative study conducted in 2014 focused on the agglomeration of Nice; it is as such an additional element that is drawn on in the context of this paper.

The qualitative study includes forty-three semi-structured interviews conducted face-toface with inhabitants of the Alpes-Maritimes (twenty-three inhabitants were interviewed in 2009 and twenty others in 2014) and five in-depth interviews conducted in 2009 with professionals from the health and mosquito control sectors. Alongside the campaign of semi-structured interviews conducted in 2009, direct observation was carried out in the form of accompanying mosquito control technicians when they conducted home visits. We also monitored the feedback meetings ("RETEX") on chikungunya and dengue organised in Paris by the General Directorate for Health in 2013, 2014 and 2015.

Table 1. Materials and methods

\begin{tabular}{|c|c|c|c|}
\hline Research programme & Locality & Year & Survey \\
\hline \multirow{3}{*}{$\begin{array}{l}\text { IMCM } \\
(2009-2013)\end{array}$} & \multirow{3}{*}{$\begin{array}{l}\text { Alpes Maritimes } \\
\text { (Coastal } \\
\text { Municipalities) }\end{array}$} & 2009 & Semi-structured interviews $(n=48)$ \\
\hline & & 2010 & First questionnaire $(\mathrm{n}=281)$ \\
\hline & & 2012 & Second questionnaire $(n=140)$ \\
\hline \multirow{4}{*}{$\begin{array}{l}\text { PROLITENSAN } \\
(2013-2016)\end{array}$} & Nice & 2014 & Semi-structured interviews $(\mathrm{n}=20)$ \\
\hline & \multirow{3}{*}{ Paris } & 2013 & \multirow{3}{*}{$\begin{array}{l}\text { Direct observation of the annual } \\
\text { feedback meeting of the General } \\
\text { Directorate for Health }\end{array}$} \\
\hline & & 2014 & \\
\hline & & 2015 & \\
\hline
\end{tabular}

The quantitative data are taken from a survey conducted by telephone. The samples were constructed based on a quota system in which three socio-economic variables were considered (age, gender and socio-professional category), to which two control variables

4 IMCM (Integrated mosquito control management), European life+ programme (2009-2013) and PROLITENSAN: Proliferation of land and marine-based coastal species of environmental and health-related importance: a comparison between mainland France (Mediterranean coast) and its overseas territories (French Antilles), funded by the Fondation de France (2013-2016). 
were added (type of habitat and municipality of residence). The data collected during these two phases form a diachronic study. The 2012 sample (140 people) was obtained from the list of respondents in 2010 (281 people).

\section{HOW STRONG IS THE CONNECTION BETWEEN CLIMATE CHANGE AND THE PROLIFERATION OF $A$. ALBOPICTUS? EXPERTS' VIEWS AND INHABITANTS' IMPRESSIONS}

For a growing percentage of the Alpes-Maritimes population interviewed, there was a clear connection between climate change and the increased proliferation of mosquitoes in their region. In 2010 , nearly $60 \%$ of the sample felt that climate change would lead to more mosquitoes in the Alpes-Maritimes; in 2012, this view was held by $75 \%$ percent of respondents. Alongside such certitude expressed by the population, the scientific literature has addressed a more complex situation. Several studies, including research by the IPCC (Intergovernmental panel on climate change), have confirmed the impact of climate change on the increasing range of vector mosquitoes (Fischer et al., 2014; Smith, 2014; ECDC, 2013). The entomological literature has increasingly focused on processes that are more complex than a simple causality between rising temperatures and biological invasion, including several environmental and societal factors (Fisher et al., 2014).

Firstly, the natural distribution area of $A$. albopictus includes both tropical and quite temperate areas (Hawley, 1988). Second, laboratory research, modelling and field observations have further confirmed the great ability of $A$. albopictus to also adapt to colder temperate climates (Hanson and Craig, 1994; Kobayaski et al., 2002; Delatte et al., 2009; Lacour et al., 2014). Third, modelling based on data collected in the south of France shows that, at the regional scale, human transportation is the most important factor in the dispersion of $A$. albopictus and that land use is a major factor in its establishment (Roche et al., 2015). ${ }^{5}$ Finally, extreme weather events are another aggravating effect that climate change has on epidemic risk with regard to the spread of exotic mosquitoes. As Roiz et al. (2015) have highlighted, the extreme precipitation that led to flooding in the region of Montpellier in 2014 contributed to increasing and extending the abundance of the disease vector $A$. albopictus, and consequently to extending the period of autochthonous transmission of chikungunya. Eleven autochthonous cases of chikungunya were in fact reported in the area during this same period. Thus, while flooding can be characteristic of the Mediterranean region, its frequency and intensity may be exacerbated by climate change (Min, 2011).

5 Similar processes have been observed by Butterworth et al. (2016) regarding Aedes aegypti and dengue fever outbreaks in the United States. Their baseline climate projections suggest that different areas with similar exposure to climate change nonetheless have a different likeliness of dengue fever outbreaks because of the social factors that influence transmission, such as housing and urban infrastructure. 
Researchers agree on the influence of two main anthropogenic factors that have encouraged the introduction and installation of A. albopictus - transportation and urbanisation (Roche et al., 2015). The intensification and acceleration of transportation at all scales has encouraged the introduction of exotic species in general (McNeely, 2001). While the flying range of $A$. albopictus is very limited (a few hundred meters), the mosquito "rides" boats, trains, buses and cars. For large geographical scales (e.g., from one continent to another), the accidental transportation of vector mosquitoes occurs primarily in the egg stage (Hawley, 1988; Medlock, 2012). For A. albopictus, the international trade in re-treaded tyres is particularly responsible (Hawley, 1988; Medlock, 2012; Schaffner, 2013). On smaller geographical scales, it is sometimes the adult mosquitoes that travel directly. In this sense, entomological monitoring of colonisation along the French Mediterranean coast has shown the role played by roadside rest areas as gateways for $A$. albopictus to gain new ground (Roiz et al., 2015).

Table 2. Knowledge about how the tiger mosquito was introduced and limiting international trade

\begin{tabular}{|c|c|c|c|c|}
\hline \multirow{2}{*}{ Answers } & \multirow{2}{*}{$\begin{array}{l}\text { Distribution } \\
\text { in } 2010(\%)\end{array}$} & \multirow{2}{*}{$\begin{array}{l}\text { Distribution } \\
\text { in } 2012(\%)\end{array}$} & \multicolumn{2}{|c|}{ Evolution 2010-2012: } \\
\hline & & & \multicolumn{2}{|r|}{$\chi^{2}$ test $(\alpha=0.1)$} \\
\hline \multicolumn{5}{|c|}{ Because of climate change, will there be more and more mosquitoes in the Alpes-Maritimes? } \\
\hline Yes & 59.92 & 75 & $\lambda$ & $\mathrm{p}$-value $=0,00283$ \\
\hline No & 24.21 & 10.71 & $\searrow$ & $\mathrm{p}$-value $=0,00283$ \\
\hline Do not know & 15.87 & 14.29 & $\searrow$ & $\mathrm{p}$-value $=0,00283$ \\
\hline \multicolumn{5}{|c|}{ How do you think the tiger mosquito arrived in France? } \\
\hline Airplane & 63.91 & 72.03 & $\rightarrow$ & \\
\hline Travellers - Immigration - Luggage & 34.59 & 65.25 & $\nearrow$ & p-value $<0.00001$ \\
\hline Do not know & 23.70 & 6.78 & $\searrow$ & $\mathrm{p}$-value $=0.00015$ \\
\hline Boat & 19.55 & 68.64 & $\nearrow$ & p-value $<0.00001$ \\
\hline Imported goods - Tyres & 18.80 & 77.12 & $\nearrow$ & $\mathrm{p}$-value $<0.00001$ \\
\hline Other & 12.03 & 4.24 & $\searrow$ & $\mathrm{p}$-value $=0.02605$ \\
\hline By itself - Flew here & 6.02 & 10.17 & $\rightarrow$ & \\
\hline \multicolumn{5}{|c|}{$\begin{array}{l}\text { To avoid the risk of a chikungunya epidemic in the Alpes-Maritimes, international trade should be } \\
\text { limited. }\end{array}$} \\
\hline Do not agree & 67.06 & 73.57 & $\rightarrow$ & Not significant \\
\hline Agree & 23.02 & 17.86 & $\rightarrow$ & Not significant \\
\hline Do not know & 9.92 & 8.57 & $\rightarrow$ & Not significant \\
\hline
\end{tabular}


The inhabitants of the Alpes-Maritimes interviewed were increasingly well informed about how the tiger mosquito was introduced to mainland France. While in 2010, 24\% of those interviewed said they did not know how the tiger mosquito arrived in mainland France, this was true for less than 7\% in 2012 (see Table 2). ${ }^{6}$ The transportation of goods, including tyres, became the most commonly mentioned means of introduction (77\% of those interviewed). In 2010, 35\% of the interviewees also mentioned the role of passenger transportation; this was true of $65 \%$ in 2012 . Those interviewed were as such aware and accepted the ties established by experts between the arrival of exotic vector mosquitoes and the globalisation of transportation. Despite this, most interviewees were not critical - and were even increasingly less critical - of globalisation: in 2010, $78 \%$ of those interviewed were opposed to the idea of limiting international trade to stop the risk of a chikungunya or dengue epidemic in the Alpes-Maritimes; this figure was $94 \%$ in 2012 (see Table 2). Urbanisation and peri-urbanisation appear to be the main anthropogenic factors behind the establishment of $A$. albopictus, originating from Southeast Asian forests (Mousson et al., 2005), in France. Entomologists have described a "process of domestication" regarding A. albopictus (Paupy et al., 2009). Urban zones - and peri-urban areas even more so - are environments particularly conducive to its development and reproduction, and provide it with ample food and shelter. The variety and abundance of micro reserves of water in these anthropogenic areas offer the mosquitoes a multitude of larval habitats: rainwater recovery barrels, fountains and basins, flower pot saucers, gutters and anything else capable of holding water. These artificial habitats offer a substitute for the hollow tree trunks and leaves of bromeliads that constitute their natural habitat in tropical forests (Silver, 2008). The ability of $A$. albopictus to colonise manmade sources of water is likely the key to its widespread and expanding range (Hawley, 1988). Increasingly artificial substrates in the environment, the loss of biodiversity, and urban expansion and densification have all encouraged the establishment and proliferation of $A$. albopictus, as well as the amplification of dengue and chikungunya epidemics (Gould et al., 2009; Ostfeld, 2009). A. albopictus feeds almost exclusively on humans in urban and peri-urban areas, as Valerio et al. (2010) have shown with regard to the province of Rome, Italy. And yet, while the inhabitants we interviewed in France had experienced on their own skin the arrival of $A$. albopictus in their neighbourhoods, gardens and homes, their awareness and acceptance of the domestic nature of this anthropophilic mosquito was nonetheless not a given. Indeed, A. albopictus transgresses two anthropological dualisms that are particularly rooted in Western culture: the notions of clean and dirty (Douglas, 2002), and of wild and domestic (Descola, 2013). The domestic nature of tiger mosquitoes, who lay their eggs in small quantities of clean water, indeed blurs the common representation in mainland France of mosquitoes being associated with the wilderness or stagnant water (Claeys

6 Interpretation of the $\chi^{2}$ tests in the different tables: $\rightarrow$ (not significant), $\searrow$ (decrease) or $\nearrow$ (increase) in statistical significance between 2010 and 2012 at the alpha level $=0.1$. 
and Mieulet, 2013). In 2009, this unique entomological attribute of the tiger mosquito was inconceivable for most of the inhabitants of the Alpes-Maritimes interviewed. The presence of domestic larval habitats was experienced as an insult, exacerbated by the fear of being stigmatised by neighbours. The inhabitants interviewed argued that the mosquitoes that bothered them came from elsewhere, from a natural environment (e.g., a nearby body of water or swamp) and / or a dirty environment (e.g., an abandoned fountain or a poorly kept nearby garden). Within the span of a few years, the idea that domestic space can be conducive to the reproduction and development of mosquitoes was accepted by most of the inhabitants interviewed, as we shall see in more detail below.

\section{THE IMPLEMENTATION AND RECEPTION OF VECTOR- CONTROL POLICY: INCREASING AMBIGUITY BETWEEN ENVIRONMENTAL AND HEALTH-RELATED CONCERNS}

The current lack of vaccines against arboviruses ${ }^{7}$ such as chikungunya, dengue and the Zika virus, and of anything other than symptomatic treatment has helped direct epidemic prevention policy towards vector control (VC) strategies. VC aims to control the vector by reducing the mosquito population and monitoring environments conducive to its reproduction. The influence of the European legal framework, as well as technical constraints mean that the VC methods developed in the context of epidemic prevention policies follow an eco-centric precautionary principle. To begin, the Stockholm Convention (22 May 2001) - related notably to the use of larvicides ${ }^{8}$ - limited the number of authorised molecules to Bacillus thuringiensis israelensis (BTI) alone, a molecule described as organic. Among other things, existing regulation bans the use of aerial spraying in inhabited areas. ${ }^{9}$ It is as such that $\mathrm{VC}$ campaigns favour taking a so-called environmental approach - i.e. targeting the mechanical suppression of potential larval habitats. ${ }^{10}$ Secondly, mosquito eradication via the use of biocides - an approach traditionally used in mainland France against native mosquito species who lay their eggs in wetlands (e.g., lagoons, ponds and swamps) - is technically ineffective against the larval habitats of $A$. albopictus, which are mainly found in urban and peri-urban areas. The legal context and technical limitations have as such encouraged the adoption of environmental methods that are a compromise between epidemic risk prevention and concern for the environment.

Nevertheless, since 2006, chikungunya and dengue fever have been on the list of diseases that require a mandatory transfer of individual data as part of the code of public

\footnotetext{
7 At present, no vaccine for Zika or chikungunya has received full approval, and a new vaccine against the dengue fever virus has recently appeared on the market and is currently only available in Mexico.

8 Chemical mosquito control can target the insects in their airborne adult phase (imagocide) or in their aquatic larval phase (larvicide).

9 Inter-ministerial order of 5 March 2004 on the airborne use of products listed in Article L.253.1 of the Rural Code.

10 Mosquito eggs hatch in water as larvae, then become aquatic pupa.
} 
health reporting and notification procedure. ${ }^{11}$ When a suspected case is reported, the Regional Health Authority (Agence Régionale de Santé) is required to summon mosquito control operators "to begin prospecting (entomological enquiry) and, when necessary, to adopt appropriate vector control measures around the suspected cases (search and elimination or treatment of larval habitats, imagocidal treatment, etc.)" (Ministry of Health and Social Affairs, 2014:10). To date, imagocidal treatments have been undertaken following the reporting of all suspected cases based on an anthropocentric precautionary principle.

While chikungunya and dengue prevention policy tends to waver between eco-centrism and anthropocentrism, the inhabitants of the Alpes-Maritimes with whom we met expressed increasingly anthropocentric positions. Indeed, calls for the pursuit or implementation of phytosanitary treatment has increased in recent years, whereas criticism vis-à-vis the negative effects of mosquito control on humans and / or nature has become far less common (see Table 3).

Table 3. Distribution of knowledge about the local policy approach to mosquito control, agreement with this approach, its potentially harmful nature, and the importance of health-related arguments in calls for mosquito eradication

\begin{tabular}{|c|c|c|c|c|c|}
\hline \multirow{2}{*}{ Questions } & \multirow{2}{*}{ Answers } & \multirow{2}{*}{ 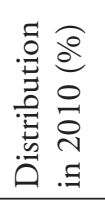 } & \multirow{2}{*}{ 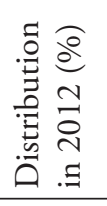 } & \multicolumn{2}{|c|}{$\begin{array}{l}\text { Evolution } \\
\text { 2010-2012: }\end{array}$} \\
\hline & & & & \multicolumn{2}{|c|}{$\chi^{2}$ test $(\alpha=0.1)$} \\
\hline \multirow{3}{*}{$\begin{array}{l}\text { To your knowledge, are mosquito } \\
\text { control methods used in the Alpes- } \\
\text { Maritimes? } \\
\text { (\% calculated based on respondents) }\end{array}$} & Yes & 33.45 & 38.57 & $\nearrow$ & \multirow{3}{*}{$\begin{array}{l}\text { p-value: } \\
0.00407\end{array}$} \\
\hline & $\mathrm{No}$ & 42.35 & 26.43 & $\searrow$ & \\
\hline & $\begin{array}{l}\text { Do not } \\
\text { know }\end{array}$ & 24.2 & 35 & $\nearrow$ & \\
\hline \multirow{3}{*}{$\begin{array}{l}\text { Are you (would you be) favourable } \\
\text { to mosquito eradication? } \\
\text { (\% calculated based on respondents) }\end{array}$} & Yes & 71.17 & 83.57 & $\nearrow$ & \multirow{3}{*}{$\begin{array}{l}\text { p-value: } \\
0.02129\end{array}$} \\
\hline & No & 20.8 & 12.14 & $\searrow$ & \\
\hline & $\begin{array}{l}\text { Do not } \\
\text { know }\end{array}$ & 8.03 & 4.29 & $\searrow$ & \\
\hline \multirow{3}{*}{$\begin{array}{l}\text { Broadly speaking, do you think that } \\
\text { mosquito eradication can be harmful } \\
\text { to health? } \\
\text { (\% calculated based on respondents) }\end{array}$} & Yes & 57.55 & 40 & $\searrow$ & \multirow{3}{*}{$\begin{array}{l}\text { p-value: } \\
0.00278\end{array}$} \\
\hline & No & 26.26 & 35 & $\nearrow$ & \\
\hline & $\begin{array}{l}\text { Do not } \\
\text { know }\end{array}$ & 16.19 & 25 & $\nearrow$ & \\
\hline $\begin{array}{l}\text { Why are you in favour it? (People } \\
\text { aware of mosquito control in the } \\
\text { Alpes-Maritimes) } \\
\text { (\% calculated based on respondents) }\end{array}$ & $\begin{array}{l}\text { Risks tied to } \\
\text { mosquitoes }\end{array}$ & 27.16 & 84.91 & $\nearrow$ & $\begin{array}{l}\text { p-value: } \\
<0.00001\end{array}$ \\
\hline
\end{tabular}

11 Articles D.3113-6 and D.3113-7. 


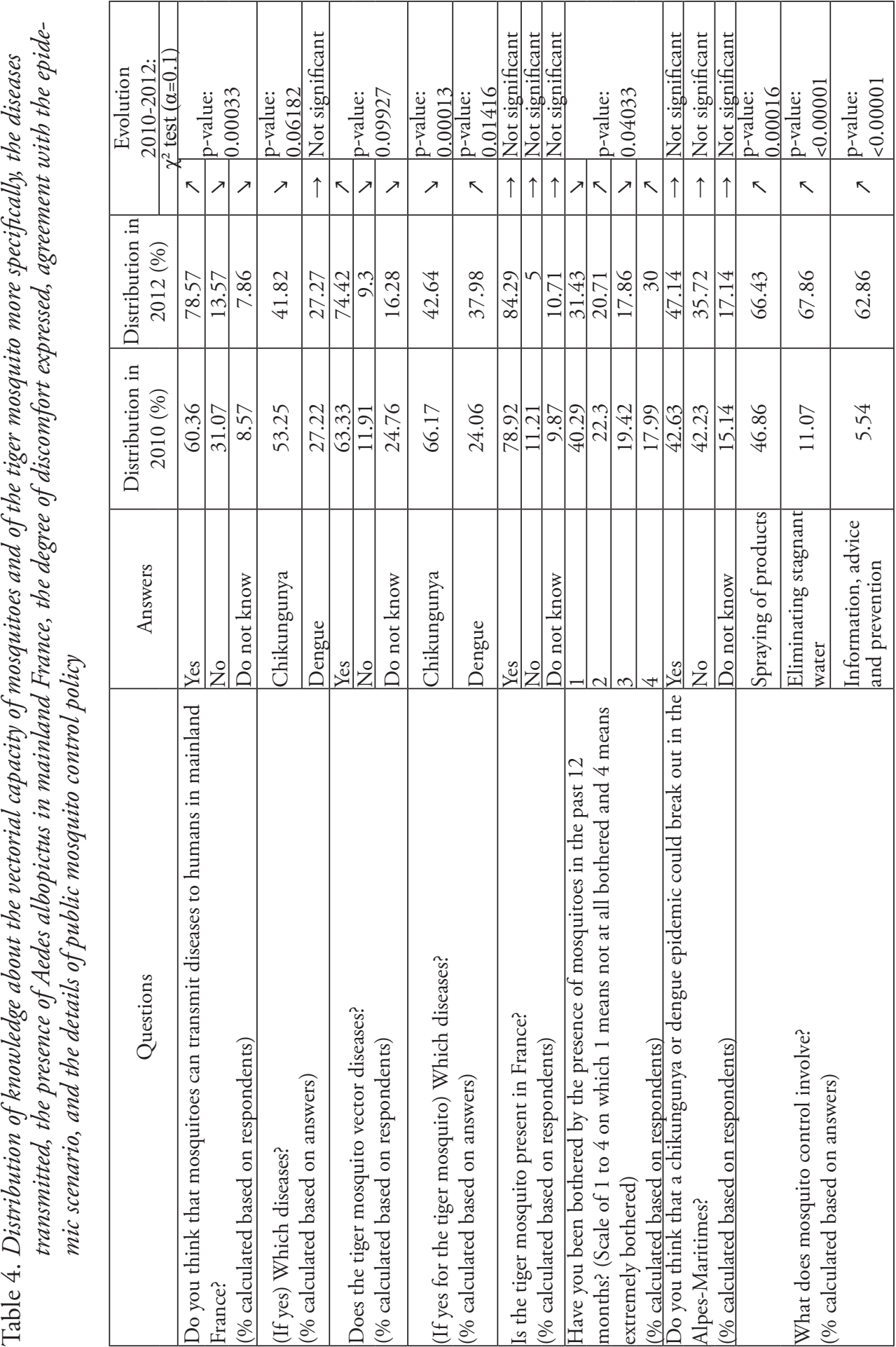


Increasingly, mentioning the harmful effects of phytosanitary treatment was not a sufficient reason for individuals to oppose mosquito control in their municipality. Thus, of the $58 \%$ of those interviewed who mentioned harmful effects in $2010,67 \%$ said they were nonetheless in favour of mosquito eradication. And of the $40 \%$ who considered that mosquito eradication was harmful in $2012,77 \%$ said they were nevertheless favourable to its implementation. It is also worth noting that regardless of the reservations expressed regarding the harmful effects of biocides, the health risk tied to mosquitoes was the leading reason given by inhabitants (in 2010 and even more so in 2012) to justify their desire for mosquito eradication (see Table 3). More than simple contradictory aspirations, such responses are also due to the invisibility and slow acting risk of biocides compared to the immediate nuisance caused by mosquito bites (Claeys and Mieulet, 2013) and the speed of epidemic outbreaks (Hlongwana, et al., 2013; Krieger, 2005).

Over the course of our study period, the health risks associated with mosquitoes became increasingly visible to the population. The proportion of inhabitants who mentioned the vector competence of the mosquitoes present in mainland France certainly increased significantly between 2010 and 2012 (see Table 3). The two most frequently mentioned pathologies were chikungunya and dengue fever, thus pointing up a cyclical effect tied to the increasingly visible presence of tiger mosquitoes, and reinforced by the simultaneous increase between 2010 and 2012 of the degree of discomfort expressed, knowledge of epidemic risks and calls for mosquito eradication (see Tables 3 and 4).

While health risks were the main reason given for the increased calls for mosquito control, the concern expressed by the inhabitants interviewed about the risk of an epidemic did not increase significantly. In $2010,43 \%$ of respondents felt that a chikungunya or dengue epidemic could break out in their department; in 2012, this represented $47 \%$ of those interviewed, which is not a statistically significant increase. Moreover, of the $42 \%$ who felt that there would not be a chikungunya or dengue epidemic in their department in $2010,66 \%$ were nevertheless in favour of mosquito eradication policy. Further still, of the $36 \%$ in 2012 who felt that there would not be a chikungunya or dengue epidemic in their department, $82 \%$ were in favour of mosquito eradication. Given this, support for mosquito control based on arguments about health may also - and even primarily - be motivated by a quest for personal comfort. A certain ambiguity nonetheless exists. Since A. albopictus is both a vector and a nuisance biter, it highlights the permeable boundary between comfort and health. While numerous indicators converge to underscore the positive influence of the quality of living conditions on health, the scientific literature must contend with the difficulty of defining and measuring this notion (Sen, 1992). From an epidermal annoyance that bothers diners on their patios to a characteristic dermic infection all the way to the transmission of dengue and chikungunya, the boundary between comfort and health is particularly porous and evolving in this case. Such taxonomic crossover is further compounded by a certain degree of administrative-legal confusion. The national government is responsible for defining the VC strategy, but its implementation falls under the auspices of local authorities, who are also in charge of conducting awareness-raising campaigns and mosquito control operations. However, 
the definition and implementation of strategies to combat nuisance biters, including so-called comfort driven mosquito-control, is the sole responsibility of local municipalities. ${ }^{12}$ And yet the entomological reality does not always comply with the layout of the French administrative system, since $A$. albopictus is both a nuisance biter and a vector. Experts agree that $\mathrm{VC}$ should involve mosquito eradication and this is reflected in the National Plan to counter the dissemination of chikungunya and dengue fever. The ambiguity found in the health arguments advanced by inhabitants of the Alpes-Maritimes, the permeability of the boundary between comfort and health, as well as the administrative confusion between $\mathrm{VC}$ and comfort-based mosquito control could thus ultimately form a modus vivendi operating for the common good, i.e. working to prevent the risk of a chikungunya and dengue epidemic. Unfortunately, the possibility of such a modus vivendi finds its limits in the notable differences between $\mathrm{VC}$ and comfort-based mosquito control techniques. In the Alpes-Maritimes, the use of biocides in the context of $\mathrm{VC}$ is limited in time and space. They are used only to eradicate $A$. albopictus around suspected cases during their viremic phase ${ }^{13}$ to counter the risk of an epidemic outbreak. Such larvicidal and imagocidal treatments reduce the nuisance in a very limited manner in time and space, particularly given that the number of suspected cases of dengue fever and chikungunya in the Alpes-Maritimes remains small. Comfort-based mosquito control involves the use of biocides that target different native mosquito species, such as $A$. detritus or Culex caspius, who lay their eggs primarily in wetlands (swamps, lagoons, ponds, etc.). In mainland France, it was implemented on a large scale starting in the 1960s in regions with a lot of wetlands (notably in Languedoc-Roussillon and around the Etang de Berre). Such comfort-based mosquito control techniques have no effect on $A$. albopictus who, as we saw above, lives mainly in anthropised urban and peri-urban areas. Given this, the differences in operating methods between comfort-based mosquito control and VC mean that it is not possible to "kill two birds with one stone", thus making it technically difficult (if not impossible) to come to a modus vivendi on this question. The inhabitants of the Alpes-Maritimes we interviewed had no or only limited knowledge of the differences between comfort-based mosquito control and VC, however, even if a notable change was evident over the span of our study. In 2010, the most common answer by far to the question "what does mosquito control involve?" was "the spraying of products". This answer remained predominant in 2012, although the quest to eliminate sources of stagnant water and information campaigns - mentioned only very rarely in 2010 - began to catch up (see Table 4). Such answers reflect the increased visibility of VC awareness-raising campaigns which emphasise the importance of eliminating sources of stagnant water. Inhabitants, however, do not always clearly differentiate between comfort-based mos-

12 Law \#64-1246 of 16 December 1964 modified by Article 72 of Law \#2004-809 of 13 August 2004 on local liberties and responsibilities, Article L. 3114-5 of the Code of Public Health.

13 For chikungunya, the viremic phase begins roughly five days after being bitten and lasts on average seven days, whereas the viremic phase for dengue begins two or three days after being bitten and lasts for seven days (Terrien, 2008). 
quito control and $\mathrm{VC}$ as showcased in the set of semi-structured interviews conducted during the summer of 2014. One inhabitant in a neighbourhood in Nice that had been the focus of imagocidal VC treatment, for example, complained: "Once, they came with a big truck at six o'clock in the morning. But they only sprayed the neighbourhood. [...] They could have done the whole city. In the end, it was useless, because you can't eradicate all the mosquitoes by only dealing with one little corner".

The desire for mosquito eradication expressed by the inhabitants we met was ultimately based more on their desire to reduce or even eliminate the nuisance. In an ambiguous manner, the health-related side of this issue was an additional argument to support calls for mosquito control more than actually being the driver behind such calls. It was an aggravating condition that allowed the urgency of the situation to be highlighted, and which further emphasised the relevance of calls for mosquito eradication and justified the arbitration between anthropocentrism and eco-centrism.

\section{POPULATIONS CONFRONTED WITH AN INVASIVE EXOTIC VECTOR MOSQUITO: (UN)ACCEPTANCE AND VULNERABILITY}

VC policy encourages the use of information campaigns. Such campaigns aim to teach inhabitants to identify, monitor and mechanically destroy potential larval habitats in their homes and gardens by eliminating or at least regularly emptying all sources of stagnant water. These awareness-raising messages have been given a great deal of visibility. In 2012, 63\% of the Alpes-Maritimes inhabitants interviewed associated mosquito control with information campaigns, compared to only $5 \%$ in 2010 . The increased visibility of such campaigns went hand in hand with improved knowledge about types of larval habitats specific to this vector mosquito. The larval habitats emphasised in awarenessraising campaigns were mentioned significantly more by inhabitants in 2012 than in 2010, notably saucers, gutters and stagnant water more broadly (see Tables 4 and 5). The prevention strategies that inhabitants claimed to employ to combat mosquitoes also evolved greatly: in 2012,100\% of the sample claimed they emptied stagnant water sources compared to only $10 \%$ in 2010 . Despite a methodological bias surrounding the way this question was asked and which requires us to nuance the observed discrepancy, the shift is nevertheless significant. ${ }^{14}$ Indeed, the unanimity surrounding the management of stagnant water particularly reflects the centrality of the issue in the VC awareness campaign entitled "Soyez secs avec les moustiques", a play on words since the word

14 This was an open-ended question in 2010, coded directly by the interviewer in person. In 2012, the interviewer read a list of options to those interviewed. This change in method was made based on field experience that showed that inhabitants tended to forget to mention certain prevention / protection techniques they used. The undesirable effect of this change was an underestimation of the diversity of prevention / protection techniques in 2010 and an overestimation (power of suggestion) in 2012. Nevertheless, the discrepancy in responses between 2010 and 2012 is so great that we hypothesise that it is not due to this methodological bias alone and actually points to veritable social change. 
"sec" means both to be "dry" and "harsh" on mosquitoes. Further, the inhabitants we met protected themselves increasingly from mosquitoes, adopting a growing number of combined chemical, mechanical and biological techniques. They no longer hesitated to equip their windows with screens and were more likely to adapt their summer clothing to include long, loose-fitting attire (see Table 5).

A comparison of the quantitative and qualitative data nonetheless reveals discrepancies in the practices that people claimed to have during the telephone survey, those described and commented on during the semi-structured interviews, and the actual practices directly observed in the field, such as backyards and gardens that still have water containers with mosquito larvae (Claeys et al., 2016). This is a classic phenomenon that has been well documented in previous studies (Bartlett-Healy et al., 2011; Bodner, 2016). There are indeed several factors that limit the acceptance and implementation of VC actions by inhabitants. In people's discourse, the domestic nature of $A$. albopictus and its larval habitats was more widely accepted. In this respect, the idea that the mosquito can lay its eggs "as soon as there is water" was mentioned increasingly often (see Table 5). The cultural incomprehension over the domestic nature of tiger mosquitoes is decreasing, but it has been replaced with new types of cognitive incomprehension. The ability of $A$. albopictus to lay its eggs in the most unexpected and inaccessible water sources (e.g., parasol bases, the armrests of deck chairs, the food bowls of pets, toys left in a corner of the garden) indeed surprised even the most vigilant inhabitants.

The political factors observed in 2010 that slowed the acceptance of awareness-raising campaigns conversely persisted and were even exacerbated. The first of these involved shifting responsibility from the private sphere to the public sphere, and the second was based on excessive confidence in public health institutions. Already a majority in 2010 , the proportion of inhabitants interviewed who said they were confident in the ability of the French healthcare system to manage a chikungunya or dengue epidemic in mainland France increased significantly in 2012 (see Table 5). And yet we know that situations of strong confidence in public institutions paradoxically tend to reduce the adoption of individual prevention measures (Taylor-Gooby and Zinn, 2006). Conversely, as particularly highlighted by the Reunion Island experience, fear of disease tends to encourage inhabitants to more closely follow the advice given in information campaigns (Duret et al., 2013). And yet there was no significant increase between 2010 and 2012 in the percentage of inhabitants who felt that a chikungunya or dengue epidemic might break out in their department, less than half of respondents in both cases (see Table 4). The use of fear in awareness-raising campaigns is a particularly controversial topic among local and national institutional actors involved in VC. During the RETEX meetings, there was growing discord between national and local bodies over this question. While the national actors advocated for clearer information on the epidemic risks and serious potential of chikungunya and dengue fever, local actors - in agreement with local elected officials or under their influence - tended to advocate for strategies that downplayed the epidemic risk and symptoms of the two diseases. While the former aimed for an optimal effect and efficiency from awareness-raising campaigns, the latter 


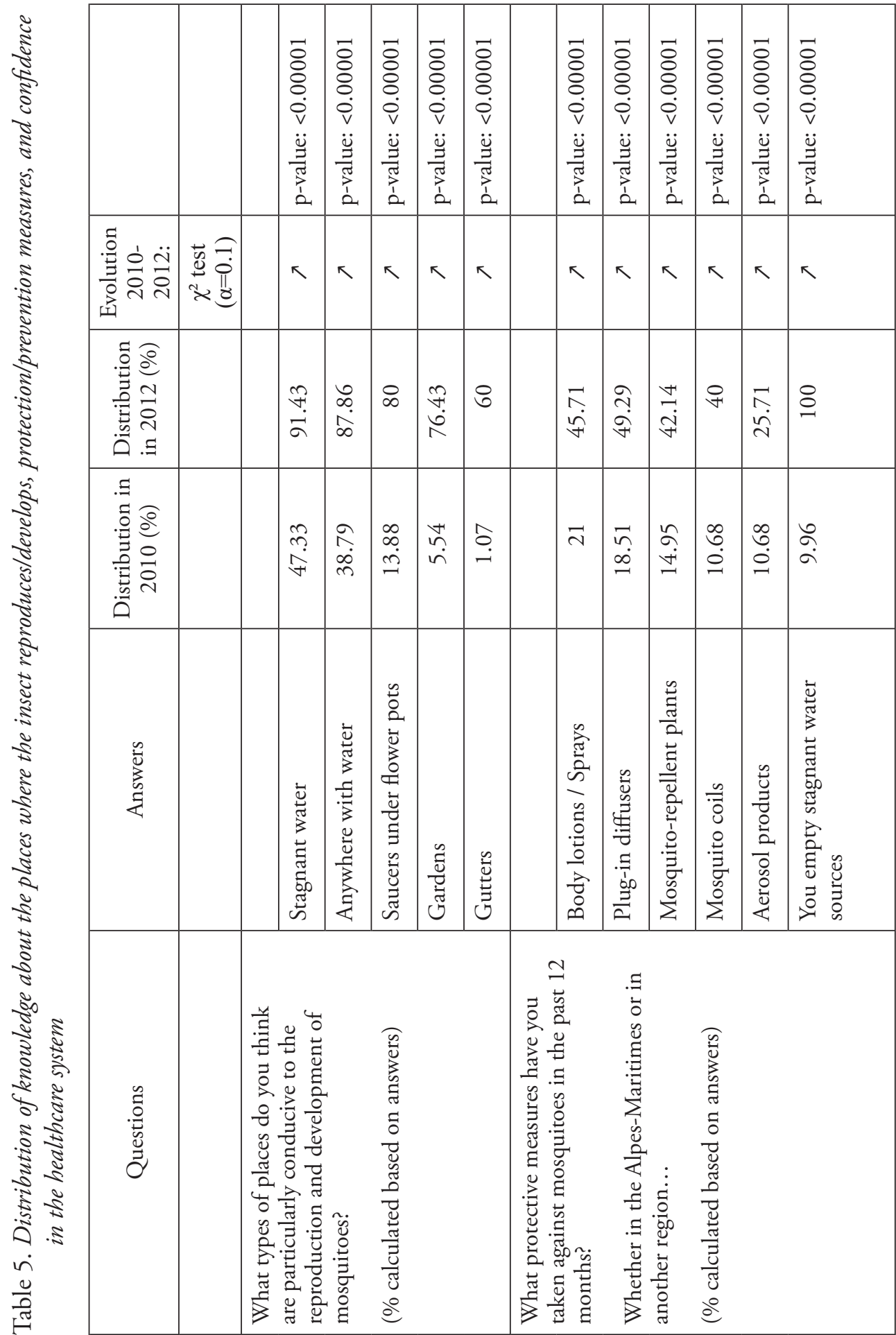




\begin{tabular}{|c|c|c|c|c|c|c|c|c|c|c|c|c|}
\hline 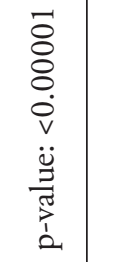 & 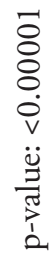 & 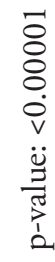 & 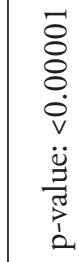 & 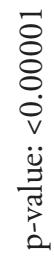 & 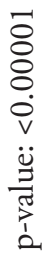 & 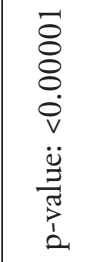 & 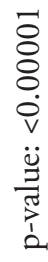 & 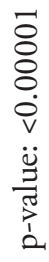 & & 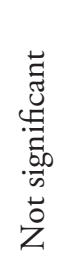 & & \\
\hline$\nwarrow$ & $\nwarrow$ & $\nwarrow$ & $\nwarrow$ & $\nwarrow$ & $\nwarrow$ & $\nwarrow$ & $\nwarrow$ & $\nwarrow$ & & $\uparrow$ & $\uparrow$ & $\uparrow$ \\
\hline $\begin{array}{l}\hat{n} \\
\hat{n}\end{array}$ & $\underset{\beth}{\stackrel{Ð}{ \pm}}$ & $\frac{ \pm}{\stackrel{\Xi}{~}}$ & $\begin{array}{l}\text { సे } \\
\text { }\end{array}$ & $\begin{array}{l}\diamond \\
\stackrel{\Xi}{~}\end{array}$ & $\begin{array}{l}\hat{n} \\
\tilde{\sim}\end{array}$ & $\begin{array}{r}\hat{\curvearrowright} \\
\dot{\sim}\end{array}$ & $n$ & $\underset{\stackrel{\sim}{\vec{\sim}}}{\stackrel{\sim}{\sim}}$ & & શิ & $\begin{array}{l}\unlhd \\
\stackrel{J}{J}\end{array}$ & $\hat{n}$ \\
\hline$\underset{Ð}{\stackrel{\overbrace{}}{\sim}}$ & $\underset{\forall}{\stackrel{\oplus}{N}}$ & 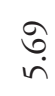 & $\stackrel{\infty}{\stackrel{\infty}{+}}$ & $\begin{array}{l}\stackrel{2}{n} \\
\dot{n}\end{array}$ & $\begin{array}{l}\mathscr{n} \\
\stackrel{\sim}{\sim}\end{array}$ & $\begin{array}{l}\mathscr{n} \\
\stackrel{\sim}{i}\end{array}$ & $\stackrel{\sim}{\stackrel{\sim}{\sim}}$ & $\stackrel{\sim}{\sim}$ & & అొْ & $\begin{array}{l}+1 \\
\infty \\
\stackrel{-}{2}\end{array}$ & $\tilde{n}$ \\
\hline 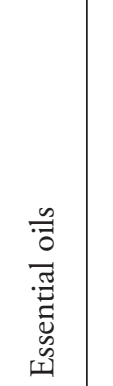 & 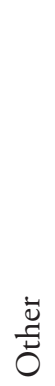 & 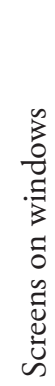 & 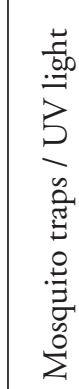 & 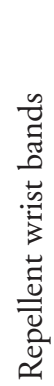 & 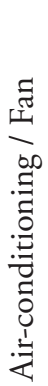 & 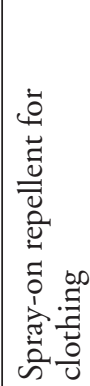 & 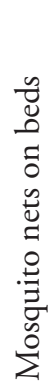 & 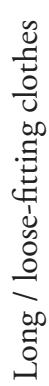 & & $\stackrel{0}{\tilde{Z}}$ & $\stackrel{\circ}{Z}$ & 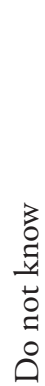 \\
\hline 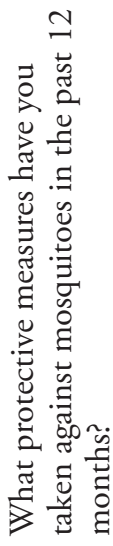 & & 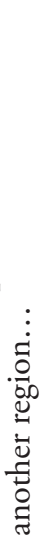 & 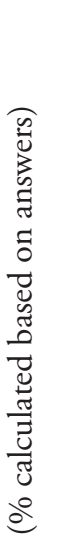 & & & & & & 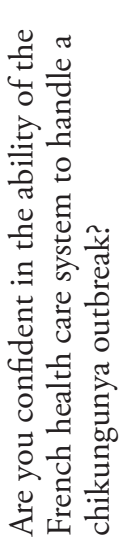 & 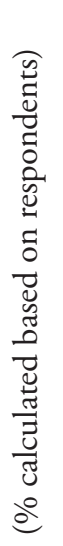 & & \\
\hline
\end{tabular}


wanted to reconcile health information and the preservation of the touristic appeal of the region - an issue with particularly high stakes in the Alpes-Maritimes.

The colonisation of urban and peri-urban areas by the tiger mosquito and its predilection for domestic larval habitats have exposed some inhabitants of the Alpes-Maritimes region more than others to bites by the vector insect. Indeed, inhabitants of single-family homes with a garden or patio claimed significantly greater discomfort levels than those who live in collective housing. This phenomenon increased over time. In 2010, 28\% of inhabitants in single-family homes mentioned a very high degree of discomfort versus $11 \%$ of those in collective housing; this was respectively $41 \%$ and $19 \%$ in 2012 . Yet access to single-family housing is a strong sign of social distinction and is closely tied to high income - particularly on the French Riviera. ${ }^{15}$ Since single-family homes with gardens encourage the presence of nuisance biter mosquitoes, the contemporary standard for quality of life and social distinction has actually become a factor of environmental vulnerability. Given that this type of habitat is particularly prone to the development of vector mosquitoes, its environmental vulnerability could lead to greater health-related vulnerability by exposing its inhabitants to dengue, chikungunya or even the Zika virus. And yet, analysis of the protection strategies adopted by inhabitants and of their access to information reveals a strong ability to act. To begin, the number of protective measures taken against mosquitoes increased significantly with income level. In 2012, 78\% of those interviewed who had a monthly income of over 5,000 euros used more than five different types of protective measures versus $14 \%$ of individuals with a monthly income of less than 1,600 euros. During the qualitative survey conducted in 2014, aside from products available in supermarkets - i.e. sprays, plug-in devices and screens - several of the wealthiest inhabitants mentioned their recent use of service providers to install and manage more complex and expensive technical devices (e.g., C02 trap networks). Their type of habitat and lifestyle exposed the wealthiest inhabitants more than others to tiger mosquito bites, but their high economic capital allowed them to react to this new environmental risk. Similarly, an unequal access to information tended to counterbalance the potential health risk to this wealthy and educated population. It was indeed better informed about the introduction of tiger mosquitoes in mainland France. The gap even widened between the two survey periods, since $85 \%$ of individuals with a university degree versus $75 \%$ of those without a high school diploma were aware of the presence of tiger mosquitoes in 2010 versus $95 \%$ and $74 \%$ respectively in 2012 . Moreover, wealthier groups were also the first to be aware of the implementation of health monitoring procedures: in $2010,30 \%$ of the wealthiest population was aware of this information versus $18 \%$ of middle class respondents and $11 \%$ of the working-class

15 And indeed, within the survey samples from 2010 (Pearson's chi-square: 15.36625 , p-value $=0.00400$ ) and 2012 (Pearson's chi-square: 15.70373, p-value $=0.00345$ ), the proportion of inhabitants living in single-family homes increased significantly with the level of income (in 2012, $88.89 \%$ of those surveyed who listed a monthly income of over 5,000 euros lived in a single-family home versus $28.57 \%$ of those who declared a monthly income of less than 1,600 euros). 
population. From this perspective, there was no accumulation of disadvantages: environmental, health and social vulnerability did not mutually reinforce each other. Such a situation could corroborate Ulrich Beck's hypothesis. The case studied here clearly highlights that, given the emergence of a new risk, socially privileged populations must contend with greater environmental vulnerability and a greater potential health risk. But analysis of their quick implementation of protection strategies highlights their ability to offset their vulnerability, underscoring once again the socially unequal ability of populations to act on issues related to the environment and health (Sen, 1992). Their economic capital provided them with access to a wide array of techniques to protect against mosquitoes, including costly devices. Their cultural capital encouraged access to information regarding the introduction of tiger mosquitoes and the subsequent health risks. Moreover, their social capital - especially among local notables - even tended to encourage local authorities to take a proactive approach to the implementation of public prevention policies. These same wealthy populations were however reluctant to change certain aspects of their behaviour or to question some of their values to reduce the introduction and proliferation of vector mosquitoes. The question of the role of international trade in the introduction of vector mosquitoes is particularly telling: the more those interviewed belonged to a group of higher socio-economic status, the more they were opposed to the idea of limiting global trade. This tendency even grew over the course of the study, with $78 \%$ of individuals of higher socio-economic status opposed in 2010 versus $94 \%$ in 2012. Yet it is precisely individuals of higher socio-economic status who are the main users of international trade, through their high levels of consumption, as well as their greater mobility both for professional and leisure purposes.

\section{CONCLUSION}

The recent introduction of a vector mosquito originating from Southeast Asia has exposed Europe to epidemic risks and nuisances previously associated with exotic areas. Climate change, international trade and urban expansion have led to the spread and establishment of this invasive vector mosquito as well as to an increased loss in biodiversity. Experts and inhabitants are unanimous about the connection between climate change and the proliferation of vector mosquitoes. However, most of the inhabitants surveyed were not prepared to question the role their way of life played in the transportation and implantation of $A$. albopictus. And yet, experts have shown that human behaviour is a direct and major factor in the transportation and establishment of $A$. albopictus, and that climate change is a further aggravating factor.

Tiger mosquitoes are particularly fond of single-family homes with gardens which, in the south of France and particularly in the Alpes-Maritimes department, are found mainly in wealthy neighbourhoods. From this perspective, the initial findings of our case study appear to highlight a process that differs from the classic compounding of environmental, health and socio-economic disadvantages. Indeed, the emergence of a health risk and the increase of a nuisance in the Alpes-Maritimes department have not 
affected socially vulnerable populations, but rather the wealthiest segments of the population. The latter find themselves caught in the boomerang effect described by Ulrich Beck (1992) to the extent that their lifestyle (e.g., mobility, level of consumption, type of habitat) actually encourages the introduction, implantation and proliferation of $A$. albopictus. Given their economic, cultural and social capital, the capacity for action of such inhabitants has, however, provided them with the means to reduce their environmental vulnerability and health risk. Moreover, at the international level, statistics show that it is still the poorest populations in terms of cultural and economic capital who are most affected by dengue, chikungunya and the Zika virus, thus confirming the prevailing situation of inequality when it comes to the environment and health. Until recently, these diseases were mainly characteristic of poor countries and were largely invisible in wealthy countries. The emergence of epidemic risk in rich countries appears to be spurring increased effort and improved mobilisation from international bodies. A first vaccine has just been approved and several others are in the trial phase. The new concern shown by rich countries regarding vector-borne diseases like dengue fever, chikungunya and Zika may not totally compensate for previous international health-related and environmental injustices, however. Firstly, in coming years, the issue may shift from social inequality in terms of epidemic risk towards social inequality in access to vaccines. Second, regardless of the potential progress in terms of vaccinations, the nuisance tied to the particularly intense bites of this mosquito will not disappear. Lastly, experience shows that even those social actors best informed about environmental concerns can be enticed by the appeal of insecticides, especially when they can afford it (Robbins, 2007; Claeys el al., 2016). The spread of A. albopictus will as such expose an increasing number of humans to nuisances and epidemic risks, in turn leading them to use more biocides whose long list of effects on health and the environment are well known and whose efficiency is declining in any case given the increased resistance of certain mosquito species. This case study points to how the interdependency between social, environmental and health-related vulnerabilities can be further exacerbated in a context of climate change.

\section{REFERENCES}

Beck, U. (1992). Risk Society, Towards a New Modernity. London: Sage Publications.

Bartlett-Healy, K., Hamilton, G., Healy, S., Crepeau, T., Unlu, I., Farajollahi, A., Fonseca, D., Gaugler, R., Clark, G. G., Strickman, D. (2011). Source reduction behavior as an independent measurement of the impact of a public health education campaign in an integrated vector management program for the Asian tiger mosquito. International Journal of Environmental Research and Public Health, 8(5): 1358-1367.

Bodner, D., LaDeau, S. L., Biehler, D., Kirchoff, N., Leisnham, P. T. (2016). Effectiveness of Print Education at Reducing Urban Mosquito Infestation through Improved Resident-Based Management. PLoS ONE, 11(5): e0155011. DOI:10.1371/ journal.pone.0155011 
Bullard, R. D. (2008). Differential Vulnerabilities: Environmental and Economic Inequality and Government Response to Unnatural Disasters. Social research, 75(3): 753-784.

Butterworth, M. K., Morin, C. W., Comrie, A. C. (2016). An Analysis of the Potential Impact of Climate Change on Dengue Transmission in the Southeastern United States. Environmental Health Perspectives, DOI: 10.1289/EHP218.

Claeys, C., Robles, C., Bertaudiere-Montes, V., Deschamps-Cottin, M., Megnifo, H. T., Pelagie-Moutenda, R., Jeannin, C., Sonor, F., Dollin, C., Sense, M., Bravet, P., Weill, L., Demerrisse, C., Mazurek, H., Arrhegini, L., Etienne, M., Yebakima, A., Gustave, J., Fouque, F. (2016). Socio-ecological factors contributing to the exposure of human populations to mosquito bites that transmit dengue fever, chikungunya and zika viruses: a comparison between mainland France and the French Antilles. Environnement, Risques \& Santé, 15(4): 318-325.

Claeys, C. and Mieulet, E. (2013). The spread of Asian tiger mosquitoes and related health risks along the French Riviera: An analysis of reactions and concerns amongst the local population. International Review of Social Research, 3(2): 151-173.

Delatte, H., Gimonneau, G., Triboire, A., Fontenille D. (2009). Influence of temperature on immature development, survival, longevity, fecundity and gonotrophic cycles of Aedes albopictus, vector of chikungunya and dengue in the Indian Ocean. Journal of Medical Entomology, 46(1): 33-41.

Descola, P. (2013). Beyond nature and culture. Chicago: University of Chicago Press.

Douglas, M. (2002). Purity and Danger: An Analysis of Concepts of Pollution and Taboo. London / New York: Routledge.

Dunlap, R. E. and York, R. (2008). The Globalization of Environmental Concern and the Limits of the Postmaterialist Values Explanation: Evidence from Four Multinational Surveys. The Sociological Quarterly 49(3): 529-563.

Duret, P., Cubizolles, S., Thiannbo, M. (2013). La crise sanitaire du chikungunya: une épreuve de recomposition des rapports sociaux à La Réunion. Sociologie, 4(3). URL: http://sociologie.revues.org/1935_(July 15, 2016).

European Centre for Disease Prevention and Control (ECDC). (2013). Environmental risk mapping: Aedes albopictus in Europe. Stockholm: ECDC.

European Commission. (2008). Attitudes of European citizens towards the environment. Special Eurobarometer 295/ Wave 68.2 - TNS Opinion \& Social.

Fischer, D., Thomas, S. M., Neteler, M., Tjaden, N. B., Beierkuhnlein, C. (2014). Climatic suitability of Aedes Albopictus in Europe referring to climate change projections: comparison of mechanistic and correlative niche modelling approaches. Eurosurveillance, 19(6): 20696. DOI: 10.2807/1560-7917.ES2014.19.6.20696.

Genchi, C., Rinaldi, L., Mortarino, M., Genchi, M., Cringoli, G. (2009). Climate and Dirofilaria infection in Europe. Veterinary Parasitology, 163(4): 286-292.

Gomes, M. (1993). Economic and demographic research on malaria: a review of the evidence. Social Science and Medicine, 37(9): 1093-1108.

Gould, E. A. and Higgs, S. (2009). Impact of climate change and other factors on emerging arbovirus diseases. Transactions of the Royal Society of Tropical Medicine and Hygiene, 103(2): 109-121. 
Hanson, S. and Craig, G. J. (1994). Cold acclimation, diapause, and geographic origin affect cold hardiness in eggs of Aedes albopictus (Diptera: Culicidae). Journal of Medical Entomology, 31(2): 192-201.

Hawley, W. A. (1988). The biology of Aedes albopictus. Journal of the American Mosquito Control Association, Supplement 1: 1-39.

Hlongwana1, K. W., Mavundza1, E. J., Mohapi, E. P., Kruger, P., Urbach, J., Mukaratirwa, S., Maharaj, R., (2013). Vector-control personnel's knowledge, perceptions and practices towards insecticides used for indoor residual spraying in Limpopo Province, South Africa. Parasites \& Vectors, 6: 118. URL: https://parasitesandvectors.biomedcentral.com/articles/10.1186/1756-3305-6-118 (July 15, 2016).

Julianio, S. A. and Lounibos, L. P. (2005). Ecology of invasive mosquitoes: effects on resident species and on human health. Ecology Letters, 8(5): 558-574.

Kent, E., Pinkerton, W., Rom, N. (2014). Global Climate Change and Public Health. New York: Pinkerton.

King, B. and Crews, K. A. (2013). Ecologies and Politics of Health. London / New York: Routledge.

Kobayashi, M., Nihei, N., Kurihara, T. (2002). Analysis of northern distribution of Aedes albopictus (Diptera: Culicidae) in Japan by geographical information system. Journal of Medical Entomology, 39(1): 4-11.

Krieger, R. (2005). Reviewing some origins of pesticide perceptions. Outlooks on Pest Management, 16: 244-248.

Lacour, G., Vernichon, F., Cadilhac, N., Boyer, S., Lagneau, C., Hance, T. (2014). When mothers anticipate: Effects of the prediapause stage on embryo development time and of maternal photoperiod on eggs of a temperate and a tropical strains of Aedes albopictus (Diptera: Culicidae). Journal of Insect Physiology, 71: 81-96.

Light, A. and Rolston, H. (2002). Environmental Ethics: Anthology. Hoboken, NJ: Wiley-Blackwell.

McNeely, J. A. (ed). (2001). The Great Reshuffling: Human Dimensions of Invasive Alien Species. Gland, Switzerland / Cambridge, UK: IUCN.

Medlock, J. M., Hansford, K. M., Schaffner, F., Versteirt, V., Hendrickx, G., Zeller, H., Van Bortel, W. (2012). A review of the invasive mosquitoes in Europe: Ecology, public health risks, and control options. Vector-Borne and Zoonotic Diseases, 12(6):435-447.

Mieulet, E. and Claeys C. (2014). The implementation and reception of policies for preventing dengue fever epidemics: a comparative study of Martinique and French Guyana. Health Risk and Society, 16(7-8): 581-599.

Min, S. K., Zhang, X., Zwiers, F.W., Hegerl, G. C. (2011). Human contribution to more-intense precipitation extremes. Nature. 470(7334):378-381.

Ministère des Affaires Sociales et de la Santé. (2014). Guide relatif aux modalités de mise en œuvre du plan anti-dissémination du chikungunya et de la dengue en metropole. Paris: Ministère des Affaires Sociales et de la Santé. 
Mol, A. P. J., Spaargaren, G., Sonnenfeld, D. A. (2009). Ecological modernisation: Three decades of policy, practice and theoretical reflection. In: Mol, A. P. J., Sonnenfeld, D.A., Spaargaren, G. (eds.), The Ecological Modernisation Reader. Environmental reform in theory and practice (pp. 3-14). London / New York: Routledge.

Ostfeld, R. S. (2009). Biodiversity loss and the rise of zoonotic pathogens. Clinical Microbiology and Infection, 15(1): 40-43.

Paupy, C., Delatte, H., Bagny, L., Corbel, V., Fontenille, D. (2009). Aedes albopictus, an arbovirus vector: From the darkness to the light. Microbes and Infection, 11(1415): $1177-1185$.

Robbins, P. (2007). Lawn People. How Grasses, Weeds, and Chemicals Make Us Who We Are. Philadelphia: Temple University Press.

Roche, B., Léger, L., L’Ambert, G., Lacour, G., Foussadier, R., Besnard, G., Barré-Cardi, H., Simard, F., Fontenille, D. (2015). The Spread of Aedes Albopictus in Metropolitan France: Contribution of Environmental Drivers and Human Activities and Predictions for a Near Future. PLoS ONE, 10(5): e0125600. DOI: 10.1371/ journal.pone.0125600.

Roiz, D., Boussès, P., Simard, F., Paupy, C., Fontenille, D. (2015). Autochthonous Chikungunya Transmission and Extreme Climate Events in Southern France. PLoS Neglected Tropical Diseases, 9(6): e0003854. DOI:10.1371/journal.pntd.0003854

Schaffner, F., Medlock, J. M., Van Bortel, W. (2013). Public health significance of invasive mosquitoes in Europe. Clinical Microbiology and Infection, 19(8): 685-692.

Sen, A. (1992). Inequality Reexamined. Oxford: Oxford University Press.

Smith, K. R., Woodward, A., Campbell-Lendrum, D., Chadee, D. D., Honda, Y., Liu, Q., Olwoch, J. M., Revich, B., Sauerborn, R. (2014). Human health: impacts, adaptation, and co-benefits. In: Field, C. B., Barros, V. R., Dokken, D. J., Mach, K. J., Mastrandrea, M. D., Bilir, T. E., Chatterjee, M., Ebi, K. L., Estrada, Y. O., Genova, R. C., Girma, B., Kissel, E. S., Levy, A. N., MacCracken, S., Mastrandrea, P. R., White, L. L. (eds.), Climate Change 2014: Impacts, Adaptation, and Vulnerability. Part A: Global and Sectoral Aspects. Contribution of Working Group II to the Fifth Assessment Report of the Intergovernmental Panel on Climate Change (pp. 709754). Cambridge / New York: Cambridge University Press.

Sutherst, R. W. (2004). Global Change and Human Vulnerability to Vector-Borne Diseases. Clinical Microbiology Reviews, 17(1): 136-173.

Tarlock, A. D. (2009). History of environmental law. Environmental laws and their enforcement. Encyclopedia of life support system, 1. URL: https://www.eolss.net/ Sample-Chapters/C04/E4-21-01.pdf (July 15, 2016).

Taylor-Gooby, P. and Zinn, J. O. (2006). Risk in social science. Oxford: Oxford University Press.

Terrien, V. (2008). Les culicidés: Transmission vectorielle des infections et parasitoses à l'Homme, Thèse pour le diplôme d'Etat de docteur en pharmacie. Nantes: Université de Nantes.

Valerio, L., Marini, F., Bongiorno, G., Facchinelli, L., Pombi, M., Caputo, B., Maroli, M., della Torre, A., (2010). Host-Feeding Patterns of Aedes albopictus (Diptera: 
Culicidae) in Urban and Rural Contexts within Rome Province, Italy. Vector-Borne and Zoonotic Diseases, 10(3): 291-294.

Vazeille, M., Jeannin, C., Martin, E., Schaffner, F., Failloux, A. (2008). Chikungunya: A risk for Mediterranean countries? Acta Tropica, 105(2): 200-202. 


\title{
KLIMATSKE PROMJENE I INVAZIVNOST BIOLOŠKIH VRSTA: LONGITUDINALNA SOCIOLOŠKA STUDIJA NADGLEDANJA ŠIRENJA AZIJSKIH TIGRASTIH KOMARACA U EUROPI
}

\author{
Cécilia Claeys i Elise Mieulet
}

\begin{abstract}
Sažetak
Posljedice klimatskih promjena po zdravlje ljudi mogu biti izravne ali i neizravne kao što je, primjerice, raspodjela vektorskih vrsta. Takav je slučaj s komarcem Aedes albopictus, koji je vektor Denge virusa, Chikungunya virusa, a potencijalno i Zika virusa. U ovom se radu istražuje pojava A. albopictusa, ili "azijskog tigrastog komarca", u francuskom departmanu Alpes-Maritimes u kojem se u Francuskoj prvi put pojavio. Rad se temelji na kvalitativnom i kvantitativnom dijakroničnom istraživanju provedenom izmecu 2009. i 2014. godines ciljem davanja vremenski ovisne sociološke analize implementacije preventivnih politika protiv Chikungunya i Denge virusa, kao i njihovog prihvaćanja među stanovništvom ovog departmana. U radu se prvo usporectuju znanstveni diskurs $i$ diskurs lokalnog stanovnistva o klimatskim i antropogenim cimbenicima koji su doveli do pojave $i$ širenja tigrastih komaraca. Nadalje, ističe se činjenica da i donositelji mjera i lokalno stanovništvo moraju uzeti u obzir i epidemiološke i okolišne izazove koji prate širenje A. albopictusa. Konačno, u radu se istražuje (ne)prihvaćanje stanovnika prema ovoj invazivnoj egzotičnoj vrsti, te se ukazuje na nejednakosti među dijelovima populacije s obzirom na mogućnosti rješavanja ovog pitanja okolišne i zdravstvene ugroze.
\end{abstract}

Keywords: departman Alpes-Maritimes, arbovirusi, klimatske promjene, dijakronična sociološka analiza, tigrasti komarci, okolis, javno zdravlje

\section{KLIMAWANDEL UND BIOLOGISCHE INVASION: EINE SOZIOLOGISCHE LÄNGSSCHNITTSTUDIE DER AUSBREITUNGSÜBERWACHUNG DER ASIATISCHEN TIGERMÜCKE IN EUROPA}

\author{
Cécilia Claeys und Elise Mieulet
}

\section{Zusammenfassung}

Die Auswirkungen des Klimawandels auf die menschliche Gesundheit können direkt aber auch indirekt sein, wie z.B. die Verteilung von Vektorarten. Um einen solchen Fall handelt es sich bei der Mücke aedes albopictus, die das Dengue-Virus, das Chikungunya-Virus, und vielleicht auch das Zika-Virus überträgt. In dieser Arbeit befassen wir uns mit der aedes albopictus, der "asiatischen Tigermücke", im französischen Département Alpes-Maritimes, wo sie in Frankreich zum ersten Mal gesichtet wurde. Die Arbeit beruht auf einer zwischen 2009 und 2014 durchgeführten qualitativen und quantitativen diachronischen Untersuchung, die es zum Ziel hatte, eine zeitabhängige soziologische Analyse der Implementierung von Präventionspolitiken gegen das Chikungunya- und das Dengue-Virus, sowie deren Rezeption von der Bevölkerung des Départements durchzuführen.

In der Arbeit wird zuerst der wissenschaftliche Diskurs mit dem Diskurs der lokalen Bevölkerung verglichen, hinsichtlich der klimatischen und anthropogenen Faktoren, die zum Erscheinen und zur Verbreitung von Tigermücken beigetragen haben. Weiterhin wird die Tatsache hervorgehoben, dass sowohl die Maßnahmenträger als auch die lokale Bevölkerung epidemiologische und ökologische die Verbreitung von aedes albopictus begleitende Herausforderungen berücksichtigen müssen. Schließlich wird die (Nicht-) Akzeptierung dieser invasiven exotischen Art von der Bevölkerung erforscht, es wird auch auf die ungleichen Möglichkeiten der Bevölkerungsteile hingewiesen im Hinblick auf die Lösung dieses Problems der Umwelt-und Gesundheitsgefährdung.

Schlüsselwörter: Département Alpes-Maritimes, Arboviren, Klimawandel, diachronische soziologische Analyse, Tigermücken, Umwelt, öffentliche Gesundheit 